\title{
Matematik Okuryazarlığı Özyeterliliğinin ve Aile Bütçesini Planlamanın Psikolojik İyi Oluş Üzerine Etkisi
}

\author{
Müge ERSOY ${ }^{1}$, Tuğçe BALKIR ${ }^{2}$, Meryem KARAAZİZ ${ }^{3}$, Fahriye BALKIR ${ }^{4}$
}

\begin{abstract}
Özet: Matematik okuryazarlığı, bireylerin günlük yaşamlarında da kullandıkları önemli bir beceridir. Bu nedenle bireylerin hayat pahalılığı karşısında sağlıklı bir psikolojik iyi oluşa sahip olabilmeleri için matematik okuryazarlığı becerisine sahip olmaları beklenmektedir. Bu bilgiler doğrultusunda yapılan çalışma ile matematik okuryazarlığın aile bütçesini belirlemedeki önemi ile aile bütçesini planlamanın, yetişkinlerin psikolojik iyi oluşları üzerinde gerçekten etkili olup olmadığının ortaya konması amaçlanmaktadır. Bu araştırma tanımlayıcı bir araştırmadır ve ilişkisel tarama modeli kullanılarak yapılmıştır. Araştırmaya KKTC'de yaşayan 18 yaş ve üzeri 173 birey dahil edilmiştir. Araştırma bulgularında yer alan istatistiksel çözümlemelerde Statistical Package for Social Sciences (SPSS ) 24.0 yazılımı kullanılmıştır. Çalışmada, katılımcıların matematik okuryazarlığı özyeterlilik ölçeği puanlar arttıkça, psikolojik iyi oluş ölçeği puanlar da artmaktadır. Bununla birlikte, aylık/yıllık okul, kurs gibi eğitim ve sağlık giderlerini hesaplayan bireylerin hesaplamayan bireylere göre psikolojik iyi oluş ölçeği puanları ve matematik okuryazarlığı öz-yeterlilik ölçeği puanları anlamlı düzeyde yüksek olduğu görülmüştür. Sonuç olarak, bireylerin matematik okuryazarlığı öz-yeterliliklerinin arttıkça, psikolojik iyi oluş hallerinin de arttığı ortaya çıkmıştır.
\end{abstract}

Anahtar Kelimeler: Matematik okuryazarlı̆̆ı, öz-yeterlik, aile bütçesini planlama, psikolojik iyi oluş

\section{Effects of Mathematics Literacy Self-efficacy and Family Budget Planning on the Psychological Well-Being}

\begin{abstract}
Mathematics literacy is an important skill that individuals use in their daily lives. Therefore, individuals are expected to have mathematical literacy skills in order to have a healthy psychological well-being. The aim of this study is to determine the importance of mathematics literacy in determining the family budget and to determine whether planning the family budget is really effective on the psychological well-being of adults. This research was a descriptive study and conducted using a relational scanning model. The population of the study consisted of 173 individuals aged 18 years and older living in TRNC. Statistical Package for Social Sciences (SPSS) 24.0 software was used for statistical analysis. In the study, as the mathematics literacy selfefficacy scale scores increased, the scores of psychological well-being scale also increased. However, it was observed that the scores of the individuals who calculated the monthly and annual education and health expenses such as psychological well-being scores and mathematics literacy self-efficacy scale scores were significantly higher than the non-calculating individuals. As a result, as individuals' self-efficacy of mathematics literacy increased, their psychological well-being also increased.
\end{abstract}

Key Words: Mathematics literacy, self-efficacy, planning family budget, psychological well-being

\footnotetext{
${ }^{1}$ Müge Ersoy, Doktora Öğrencisi, Atatürk Eğitim Fakültesi, Rehberlik ve Psikolojik Danışmanlık Bölümü, Yakın Doğu Üniversitesi, Lefkoşa-Kıbrıs

${ }^{2}$ Tuğçe Balkır, Doktora Öğrencisi, Atatürk Eğitim Fakültesi, Rehberlik ve Psikolojik Danışmanlık Bölümü,Yakın Doğu Üniversitesi, Lefkoşa-Kıbrıs

${ }^{3}$ Yrd. Doç. Dr. Meryem Karaaziz, Yakın Doğu Üniversitesi, Fen-Edebiyat Fakültesi, Psikoloji Bölümü, Lefkoşa-Kıbrıs.

${ }^{4}$ Fahriye Balkır, Doktora Öğrencisi, Yakın Doğu Üniversitesi, Fen-Edebiyat Fakültesi, Psikoloji Bölümü, Lefkoşa-Kıbrıs. Address of correspondence/Yazışma adresi: Yrd. Doç. Dr. Meryem Karaaziz, Yakın Doğu Üniversitesi, Fen-Edebiyat Fakültesi, Psikoloji Bölümü, Lefkoşa-Kıbrıs. Email: meryem.karaaziz@neu.edu.tr

Date of Received/Geliş Tarihi: 16.04.2019, Date of Acceptance/Kabul Tarihi: 30.04.2019

Citing/ Referans Gösterimi: Ersoy, M., Balkır, T., Karaaziz, M., Balkır, F. (2019). Matematik Okuryazarlığı

Özyeterliliğinin ve Aile Bütçesini Planlamanın Psikolojik İyi Oluş Üzerine Etkisi. Kıbrıs Türk Psikiyatri ve Psikoloji Dergisi, 1(1): 31-41 doi:10.35365/ctjpp.19.1.04
} 


\section{Giriş}

Hayat pahal11lğ 1 ve düşük sosyoekonomik düzey insanoğlunu sıkıntıya sokan başlıca stres kaynakları olarak düşünülebilirler. İnsanlar stres yaratan bir durumla karşılaşmamak, rahat geçim sağlayabilmek amacıyla gelir ve giderlerine göre aile bütçe planlaması yapma gereği duyabilirler. Bireyler ve aileler rahat geçim sağlayabilmek ve stres yaratan durumlardan kurtulmak için maddi konularda bazı davranışlarını değiştirerek ya da yeni alışkanlıklar edinerek yaşam kalitelerini arttırabilir, maddi yönden bağımsızlıklarını kazanabilir ve ayakları üzerinde durabilirler (Şarlak, 2012).

Bireylerin kendi gelir ve giderlerine göre bütçe planı hazırlamaları, maddi durumun kontrolünü sağlayabilmek amacıyla geliştirilen bir alışkanlık olarak düşünülebilir. Gelir ve giderleri hesaplayarak bir bütçe planı hazırlanması için bireylerin matematik okuryazarlığı becerisine sahip olmaları beklenmektedir.

Matematik okuryazarlığı kişiye, günlük yaşam ile ilişkili uygulamaları yapabilmeyi, becerilerini geliştirebilmesini, sayısal ve uzamsal düşünmede yorumlama yapabilmesini sağlamaktadır. Aynı zamanda bireyde güven duygusunu geliştirerek, aile bütçesini hesaplama gibi günlük hayattaki problemlerin çözümünde de kolaylık sağladığı söylenebilir (Bindak ve Özgen, 2008).

Teknolojinin hızla değişip, gelişmesiyle bireylerin bilgi okuryazarı, fen okuryazarı, matematik okuryazarı olması zorunlu hale gelmiştir (Güneş ve Gökçek, 2013). Matematik olmadan bilim, bilim olmadan da teknolojiden söz etmenin imkansiz olduğu düşünüldüğüunde, bilim ve teknolojiyi geliştirmede matematiksel düşünme ve akıl yürütme, matematiksel dili ve yöntemleri kullanmak, zorunluluk olarak düşünülmektedir. Matematik, dil, semboller ve sosyal etkileşimler ile kişiye dünyayı anlamayı ve fikir geliştirmeyi öğretmektedir (Zehir ve Zehir, 2016). Matematik okuryazarlığı ise, bireyin günlük hayatta ve iş hayatında karşılaştı̆̆ nicel durumlara etkili bir şekilde katılabilmesi için gereksinim duyduğu bilgi, beceri, inanç, eğilim, zihinsel alışkanlıklar, iletişim ve problem çözme becerilerinin toplamı olarak tanımlanmaktadır (Altıntaş, Özdemir ve Kerpiç, 2012).

Matematik okuryazarı becerisine sahip bireyler günlük yaşamlarında da matematiksel bilgiyi kullanarak, mantıklı kararlar alabilirler. Matematik okuryazarlık becerisini kullanarak aile bütçesini planlayan yetişkinler kendilerini daha rahat, daha mutlu ve daha huzurlu hissetmektedirler. Bu durumda onların psikolojik iyi oluş düzeylerini olumlu yönde etkilemektedir.

Psikolojik iyi olma, kişinin kendini olumlu algılamasını, kendinden memnun olmasını, diğerleriyle güvenli ve sıcak ilişkiler geliştirmesini, kişisel ihtiyaç ve isteklerini karşılayacak şekilde çevreyi şekillendirmesini, özerk ve bağımsız hareket edebilmesini, yaşam amacının ve anlamının olmasını, kapasitesinin farkında olmasını ve bu kapasitesini geliştirmeye çalışmasını içermektedir (Kaplan, 2016).

Uzmanlara göre psikolojik iyi oluş hali bireylere yaşamlarında pek çok olumlu sonuç yaratmaktadır. Psikolojik açıdan iyi olan bireylerin, başta fiziksel ve zihinsel sağlıkları olmak üzere, kendilerine olan güvenlerinin, olumlu düşünme biçimlerinin, iş ve özel hayat tatminlerinin daha yüksek olması beklenmektedir. Bu nedenle, yüksek psikolojik iyi oluş, bireysel performans üzerinde olumlu etki yaratarak, bireylerin yaşamdan zevk almalarını ve yaşamdan memnun olmalarını sağlamaktadır (Akdoğan ve Polatc1, 2013).

\section{Araştırmanın Amacı}

Matematik okuryazarlığı, bireylerin günlük yaşamlarında da kullandıkları önemli bir beceridir. $\mathrm{Bu}$ nedenle bireylerin hayat pahalılığ karşısında sağlıklı bir psikolojik iyi oluşa sahip olabilmeleri için matematik okuryazarlığı becerisine sahip olmaları beklenmektedir. Bu bilgiler doğrultusunda yapılan çalışma ile Matematik Okuryazarlığın aile bütçesini belirlemedeki önemi ile aile bütçesini planlamanın, yetişkinlerin psikolojik iyi oluşları üzerinde gerçekten etkili olup olmadığının ortaya konması amaçlanmaktadır.

Bu çalışmada, yukarıda tanımlamaları yapılan tüm bu kavramlar ve kuramlar işığında, çalışmada araştırılan temel soru şudur: "Matematik okuryazarlığın aile bütçesini belirlemedeki önemi nedir ve aile bütçesini planlamak, yetişkinlerin psikolojik iyi oluş düzeylerini etkilemekte midir"? şeklindedir. Araştırmanın problemine ilişkin bulguları ortaya koyabilmek için aşağıdaki alt problemlere yanıt aranmışırı:

1- Bireylerin, aile bütçesi planlaması yapma durumları nedir?

2- Bireylerin, psikolojik iyi oluş düzeyleri;

- Cinsiyetlerine,

- Yaşlarına,

- Eğitim Durumu,

- Medeni duruma,

- Çocuk Sahibi olma,

- Geniş ve çekirdek ailede yaşamalarına göre değişkenlik göstermekte midir?

3- Bireylerin, Matematik Okuryazarlığ yeterlik becerileri;

- Cinsiyetlerine,

- Yaşlarına,

- Eğitim Durumu,

- Medeni duruma,

- Çocuk Sahibi olma, 
- Geniş ve çekirdek ailede yaşamalarına göre değişkenlik göstermekte midir?

4- Bireylerin psikolojik iyi oluş düzeyleri ile matematik okuryazarlığı öz-yeterlilik becerileri arasında anlamlı bir ilişki var mıdır?

\section{Yöntem}

$\mathrm{Bu}$ bölümde araştırma modeli, araştırma grubu, verilerin toplanması ve verilerin analizi yer almaktadır.

\section{Araștırma Modeli}

$\mathrm{Bu}$ araştırmada ilişkisel tarama modeli kullanılmıştır. İlişkisel tarama modelleri iki ve daha çok sayıdaki değişken arasında birlikte değişim varlığını veya derecesini belirlemeyi amaçlayan araştırma modelleri olarak tanımlanmaktadır ( Akt. Güler ve Eroğlu, 2015).

\section{Evren ve Örneklem}

Araştırmaya Kuzey Kıbrıs Türk Cumhuriyeti'nde yer alan 18 yaş ve üzeri uygun örnekleme yöntemi ile seçilmiş 178 birey dahil edilmiştir.

\section{Verilerin Toplanması}

Araştırma verileri 4 bölümden oluşan anket formu aracılığıyla toplanmıştır. Formun birinci bölümünde katılımcıların yaş, cinsiyet, eğitim durumu gibi demografik özelliklerinin saptanması amaciyla yöneltilmiş sorular yer almaktadır. İkinci bölümde katılımcıların aile bütçesi planlama durumlarına yönelik sorular yer almaktadır. Formun üçüncü ve dördüncü bölümlerinde ise psikolojik iyi oluş ölçeği ve matematik okuryazarlığı öz-yeterlilik ölçeği bulunmaktadır.

\section{Matematik Okuryazarlıklarına Öz-Yeterlilik Ölçeği}

Özgen ve Bindak (2008) tarafından geliştirilen ölçek, bireylerin matematik okuryazarlıklarına ilişkin öz-yeterliklerinin belirlenmesi amacıyla kullanılmıştır. Ölçek 5'li derecelendirme kullanılarak hazırlanmış 25 önermeden oluşmaktadır. Ölçekte yer alan olumlu önermelere verilen yanitlar tamamen katıliyorum 5 puan, tamamen katılmıyorum 1 puan olacak şekilde, olumsuz önermeler ise ters puanlanmaktadır. Ölçekten alınan yüksek puan matematik okuryazarlığı öz-yeterliliğinin yüksek olduğu ifade etmektedir. Ölçek tek boyutlu olup, ölçeğe ait Cronbach alfa katsayısının 0,97 olduğu görülmüştür (Özgen ve Bindak, 2008). Araştırmacı tarafından yapılan güvenirlik analizi sonucunda Cronbach alfa iç tutarlılık katsayısının 0,93 olduğu görülmüştür.

\section{Psikolojik İyi Oluş Ölçeği}

Psikolojik İyi Oluş Ölçeği, Sekiz maddeden oluşmakta, olumlu ilişkilerden yeterlik hislerine, anlamlı ve amaçlı bir yaşama sahip olmaya kadar insan fonksiyonunun önemli öğelerini tanımlamaktadır. Diener ve arkadaşları (2009) ölçeğin ismini önce Psikolojik İyi Oluş Ölçeği (Psychological Well-Being Scale) olarak adlandırmışlardır. Fakat daha sonra maddeleri daha iyi yansıttığı düşünülen ölçeğe "Flourishing Scale" ismini vermişlerdir. Bu araştırmada "Flourishing" kelimesinin tam olarak Türkçe karşıllı̆ 1 bulunamadığından dolayı ölçeğin ismi "Psikolojik İyi Oluş Ölçeği” olarak kullanılmıştır. Psikolojik İyi Oluş Ölçeği'nin maddeleri kesinlikle katılmiyorum (1) ile kesinlikle katılıyorum (7) şeklinde 1-7 arasında cevaplanmaktadır. Bütün maddeler olumlu şekilde ifade edilmektedir. Puanlar 8 (tüm maddelere kesinlikle katılmıyorum cevabı verilirse) ile 56 (tüm maddelere kesinlikle katılıyorum cevab1 verilirse) arasında değişmektedir. Yüksek puan kişinin birçok psikolojik kaynak ve güce sahip olduğunu gösterir. Üniversite öğrencileri ile yapılan geçerlik çalışması sonucunda ölçeğin tek faktörden oluştuğu ve toplam açıklanan varyansın \%53 olduğu saptanmıştır. Ölçek maddelerinin faktör yükleri. 61 ile. 77 arasında değişmektedir. Ölçeğin Cronbach alfa iç tutarlık katsayısı. 87 olarak bulunmuştur (Diener ve ark. 2010).

\section{Verilerin Analizi}

Araştırma bulgularında yer alan istatistiksel çözümlemelerde Statistical Package for Social Sciences (SPSS ) 24. 0 yazılımı kullanılmıştır. Katılımcıların tanıtıcı özelliklerine psikolojik iyi oluş ölçeği ve matematik okuryazarlığı öz-yeterlilk ölçeğinden aldıkları puanların normal dağılma uyumu Kolmogorov-Smirnov testi, QQ plot grafiği ve çarpıklık-basıklık katsayıları incelenerek belirlenmiş ve normal dağılıma uyduğu saptanmıştır. $\mathrm{Bu}$ sebeple araştırmada parametrik hipotez testleri kullanılmış olup, bağımsız değişkenin 2 kategoriden oluştuğu karşılaştırmalarda bağımsız örneklem t testi, 2'den fazla kategoriden oluştuğu karşılaştırmalarda ise ANOVA kullanılmıştır. Ayrıca ANOVA sonuçlarına göre bağımsız değişkenin grupları arasında fark olduğu durumlarda, farkın hangi gruptan kaynaklandığ 1 Tukey testi ile saptanmıştır. 


\section{Bulgular}

Tablo 1. Katılımcıların tanıtıcı özellikleri

\begin{tabular}{|c|c|c|}
\hline Tanıtıcı Özellikler & $\mathbf{n}$ & $(\%)$ \\
\hline \multicolumn{3}{|l|}{ Cinsiyet } \\
\hline Kadın & 108 & 62,43 \\
\hline Erkek & 65 & 37,57 \\
\hline \multicolumn{3}{|l|}{ Yaş grubu } \\
\hline $18-31$ yaş & 81 & 46,82 \\
\hline $32-42$ yaş & 30 & 17,34 \\
\hline 43-55 yaş & 40 & 23,12 \\
\hline 55 yaş ve üstü & 22 & 12,72 \\
\hline \multicolumn{3}{|l|}{ Öğrenim durumu } \\
\hline Lise & 33 & 19,08 \\
\hline Lisans & 84 & 48,55 \\
\hline Lisansüstü & 56 & 32,37 \\
\hline \multicolumn{3}{|l|}{ Medeni durum } \\
\hline Evli & 106 & 61,27 \\
\hline Bekar & 48 & 27,75 \\
\hline Boşanmış & 19 & 10,98 \\
\hline \multicolumn{3}{|c|}{ Çocuk sahibi olma durumu } \\
\hline Olan & 106 & 61,27 \\
\hline Olmayan & 67 & 38,73 \\
\hline \multicolumn{3}{|l|}{ Aile tipi } \\
\hline Çekirdek aile & 151 & 87,28 \\
\hline Geniş aile & 22 & 12,72 \\
\hline \multicolumn{3}{|l|}{ Gelir durumu } \\
\hline İyi & 79 & 45,66 \\
\hline Orta & 81 & 46,82 \\
\hline Kötü & 13 & 7,51 \\
\hline
\end{tabular}

Tablo 1.'de katılımcıların cinsiyet, yaş grubu, gelir durumu gibi sosyo-demografik özelliklerine göre dağılımı verilmiştir.

Tablo 1. incelendiğinde katılımcıların \%62,43’ünün kadın ve 37,57'sinin erkek olduğu, \%46,82'sinin 18-31 yaş grubunda, \%17,34'ünün 32-42 yaş, $\% 23,12$ 'sinin $43-55$ yaş ve $\% 12,72$ 'sinin 55 yaş ve üstü yaş grubunda yer aldı̆̆ $1, \% 19,08$ 'inin lise, \%48,55'inin lisans ve \%32,37'sinin lisansüstü mezunu olduğu saptanmıştır. Katılımcıların \%61,27'sinin evli, \%27,75'inin bekar olduğu, $\% 61,27$ 'sinin çocuk sahibi olduğu, \%87,28'inin çekirdek aileye sahip olduğu tespit edilmiştir. Katılımciların \%45,66's1 gelir durumunu iyi, $\% 46,82$ 'ini orta ve $\% 7,51$ 'i kötü olarak tanımlamıştır.

Tablo 2. Katılımcıların aile bütçesi planlaması yapma durumları $(n=173)$

\begin{tabular}{lcccc}
\hline & \multicolumn{3}{c}{ Evet } & \multicolumn{2}{c}{ Hayır } & & & \\
& n & $\%$ & $\mathbf{N}$ & $\%$ \\
\hline Aylık/haftalı bütçe planlaması yapma & 123 & 71,10 & 50 & 28,90
\end{tabular}


Kredi kartı harcamalarındaki gider farklılıklarını hesaplama

Aylık Elektrik/su/telefon/gaz gibi giderlerdeki farklılıkları hesaplama

Günlük yiyecek, içecek harcamalarını hesaplama

Aylık/yıllık ev eşyası, giyim, araba alımı, tatil,

ulaşım, yakıt, sigorta gibi giderleri hesaplama

$135 \quad 78,03 \quad 38 \quad 21,97$

Aylık/yıllık okul, kurs gibi eğitim ve sağlık giderleri hesaplama

$109 \quad 63,01 \quad 64 \quad 36,99$

Tablo 2.'de araştırmaya dahil edilen bireylerin aile bütçesi planlaması yapma durumlarına göre dağılımı verilmiştir.

Tablo 2.'de verilen sonuçlar incelendiğinde, katılımcıların \%71,10'unun aylık/haftalık bütçe planlaması yaptığı saptanmıştır. Araştırma kapsamına alınan bireylerin \%71,68'inin kredi kartı harcamalarındaki gider farklılıklarını hesapladığ1, \%63,01'inin aylık elektrik/su/telefon/gaz gibi giderlerdeki farklılıkları ve $\% 51,45^{\prime}$ 'inin günlük yiyecek, içecek harcamalarını hesapladığı tespit edilmiştir. Katılımcıların \%78,03'ünün aylık/yıllık ev eşyası, giyim, araba alımı, tatil, ulaşım, yakıt, sigorta gibi giderlerini ve \%63,01'inin aylık/yıllık okul, kurs gibi eğitim ve sağlık giderleri hesapladığ saptanmıştır.

Tablo 3. Katılımcıların psikolojik iyi oluş ölçeği ve matematik okuryazarlığı öz-yeterlilik ölçeğinden aldıkları puanlar $(\mathrm{n}=173)$

\begin{tabular}{cccccc}
\hline & $\mathbf{n}$ & $\overline{\boldsymbol{x}}$ & $\mathbf{S}$ & Min & Max \\
\hline $\begin{array}{c}\text { Psikolojik İyi } \\
\text { Olma Ölçeği }\end{array}$ & 173 & 46,68 & 4,68 & 34 & 56 \\
\hline $\begin{array}{c}\text { Matematik Okuryazarlığı } \\
\text { Öz-Yeterlik Ölçeği }\end{array}$ & 173 & 84,84 & 15,57 & 25 & 125 \\
\hline
\end{tabular}

Tablo 3.’te araştırma kapsamına alınan bireylerin psikolojik iyi oluş ölçeği ve matematik okuryazarlı̆̆ı öz-yeterlilik ölçeğinden aldıkları puanlara ilişkin tanımlayıcı istatistikler verilmiştir.

Tablo 3. incelendiğinde, katılımcıların psikolojik iyi oluş ölçeğinden ortalama $46,68 \pm 4,68$ puan aldığ 1 saptanmıştır. Katılımcıların psikolojik iyi oluş ölçeğinden aldıkları en düşük puanın 34 ve yüksek puanın 56 olduğu saptanmıştır.

Katılımcıların matematik okuryazarlığı öz-yeterlilik ölçeğinden aldıkları puanlar incelendiğinde, ölçekten alınan en düşük puanın 25 , en yüksek puanın ise 125 olduğu saptanmıştır. Katılımcıların matematik okuryazarlığı öz-yeterlilik ölçeğinden aldıkları puan ortalaması $84,84 \pm 15,57$ 'dir.

Tablo 4. Katılımcıların cinsiyetlerine, çocuk sahibi olma durumuna ve aile tipine göre psikolojik iyi oluş ölçeği puanlarının karşılaştırılması $(n=173)$

\begin{tabular}{|c|c|c|c|c|c|}
\hline & $\mathbf{n}$ & $\bar{x}$ & $\mathbf{s}$ & $\mathbf{t}$ & $\mathbf{P}$ \\
\hline \multicolumn{6}{|l|}{ Cinsiyet } \\
\hline Kadın & 108 & 46,15 & 4,67 & $-1,93$ & 0,06 \\
\hline Erkek & 65 & 47,55 & 4,60 & & \\
\hline \multicolumn{6}{|c|}{ Çocuk sahibi olma durumu } \\
\hline Olan & 106 & 46,70 & 4,53 & 0,08 & 0,94 \\
\hline Olmayan & 67 & 46,64 & 4,95 & & \\
\hline \multicolumn{6}{|l|}{ Aile tipi } \\
\hline Çekirdek aile & 151 & 46,54 & 4,75 & $-1,03$ & 0,30 \\
\hline Geniş aile & 22 & 47,64 & 4,15 & & \\
\hline
\end{tabular}


Katılımcıların cinsiyetlerine, çocuk sahibi olma durumuna ve aile tipine göre psikolojik iyi oluş ölçeği puanlarının karşılaştırılmasına ilişkin bağımsız örneklem $\mathrm{t}$ testi sonuçları Tablo 4.'te verilmiştir.
Tablo 4. incelendiğinde katılımcıların cinsiyetlerine, çocuk sahibi olma durumuna ve aile tipine göre psikolojik iyi oluş ölçeği puanları arasın istatistiksel olarak anlamlı bir fark olmadığ saptanmıştır $(\mathrm{p}>0,05)$.

Tablo 5. Katılımcıların Yaş grubu, eğitim, gelir ve medeni durumlarına göre psikolojik iyi oluş ölçeği puanlarının karşılaştırılması $(\mathbf{n}=173)$

\begin{tabular}{|c|c|c|c|c|c|c|c|c|}
\hline & $\mathbf{N}$ & $\bar{x}$ & $\mathbf{s}$ & Min & Max & $\mathbf{F}$ & $\mathbf{P}$ & Fark \\
\hline \multicolumn{9}{|l|}{ Yaş Grubu } \\
\hline $18-31$ yaş & 81 & 47,00 & 4,69 & 36 & 56 & 0,594 & 0,620 & \\
\hline $32-42$ yaş & 30 & 47,00 & 4,98 & 35 & 56 & & & \\
\hline 43-55 yaş & 40 & 45,85 & 4,64 & 39 & 55 & & & \\
\hline 55 yaş ve üstü & 22 & 46,55 & 4,42 & 34 & 52 & & & \\
\hline \multicolumn{9}{|c|}{ Eğitim Durumu } \\
\hline Lise & 33 & 45,24 & 4,13 & 37 & 53 & 2,087 & 0,127 & \\
\hline Lisans & 84 & 47,19 & 4,65 & 35 & 56 & & & \\
\hline Lisansüstü & 56 & 46,75 & 4,93 & 34 & 56 & & & \\
\hline \multicolumn{9}{|l|}{ Gelir durumu } \\
\hline İyi & 79 & 47,65 & 4,15 & 37 & 56 & 3,269 & $0,040^{*}$ & $1-2$ \\
\hline Orta & 81 & 45,79 & 5,03 & 34 & 56 & & & \\
\hline Düşük & 13 & 46,31 & 4,70 & 36 & 51 & & & \\
\hline \multicolumn{9}{|c|}{ Medeni Durum } \\
\hline Evli & 106 & 46,63 & 4,55 & 34 & 56 & 0,244 & 0,784 & \\
\hline Bekar & 48 & 46,50 & 5,16 & 35 & 56 & & & \\
\hline Boşanmış & 19 & 47,37 & 4,30 & 40 & 56 & & & \\
\hline
\end{tabular}

Tablo 5.'te katılımcıların yaş grubu, eğitim, gelir ve medeni durumlarına göre psikolojik iyi oluş ölçeği puanlarının karşılaştırılması amacıyla yapılan varyans analizi (ANOVA) sonuçları verilmiştir.

Tablo 5. incelendiğinde, araştırma kapsamına alınan bireylerin yaş gruplarına, eğitim ve medeni durumlarına göre psikolojik iyi oluş ölçeğinde aldıkları puanlar arasında istatistiksel olarak anlamlı bir fark olmadığg saptanmıştır ( $\mathrm{p}>0,05)$.
Katılımcıların gelir durumlarına göre psikolojik iyi oluş ölçeği puanları arasındaki farkın istatistiksel olarak anlamlı olduğu tespit edilmiştir $(p<0,05)$. Bu fark gelir durumunu iyi ve orta olarak tanımlayan bireylerden kaynaklanmakta olup, gelir durumunu iyi olarak tanımlayan katılımcıların psikolojik iyi oluş ölçeğinden aldıkları puanlar gelir durumunu orta olarak tanımlayanlara göre anlamlı düzeyde yüksektir.

Tablo 6. Katılımcıların cinsiyetlerine, çocuk sahibi olma durumuna ve aile tipine göre matematik okuryazarlığı öz-yeterlilik ölçeği puanlarının karşılaştırılması (n=173)

\begin{tabular}{lccccc}
\hline & $\mathbf{n}$ & $\overline{\boldsymbol{x}}$ & $\mathbf{s}$ & $\mathbf{T}$ & $\mathbf{P}$ \\
\hline Cinsiyet & & & & & \\
Kadın & 108 & 82,31 & 14,35 & $-2,81$ & $0,01^{*}$ \\
Erkek & 65 & 89,05 & 16,69 & & \\
\hline
\end{tabular}


Çocuk sahibi olma durumu

\begin{tabular}{lccccc} 
Olan & 106 & 84,40 & 14,47 & $-0,47$ & 0,64 \\
Olmayan & 67 & 85,55 & 17,25 & & \\
\hline Aile tipi & & & & & \\
Çekirdek aile & 151 & 84,63 & 16,43 & $-0,47$ & 0,64 \\
Geniş aile & 22 & 86,32 & 7,45 & & \\
\hline
\end{tabular}

$* p<0,05$

Araştırmaya dahil edilen bireylerin cinsiyetlerine göre matematik okuryazarlığı öz-yeterlilik ölçeği puanları arasında istatistiksel olarak anlamlı bir fark olduğu tespit edilmiştir $(\mathrm{p}<0,05)$. Erkek bireylerin matematik okuryazarlığı öz-yeterlilik ölçeği puanları, kadın bireylere göre daha yüksek bulunmuştur.
Katılımcıların çocuk sahibi olma ve aile tiplerine göre matematik okuryazarlığı öz-yeterlilik ölçeği puanları arasındaki farkın istatistiksel olarak anlamlı olmadı̆̆ saptanmıştır $(\mathrm{p}<0,05)$.

Tablo 7. Katılımcıların yaş grubu, eğitim, gelir ve medeni durumlarına göre matematik okuryazarlığı özyeterlilik ölçeği puanlarının karşılaştırılması $(n=173)$

\begin{tabular}{|c|c|c|c|c|c|c|c|c|}
\hline & $\mathbf{N}$ & $\overline{\bar{x}}$ & $\mathbf{S}$ & Min & Max & $\mathbf{F}$ & $\mathbf{p}$ & Fark \\
\hline \multicolumn{9}{|l|}{ Yaş Grubu } \\
\hline $18-31$ yaş & 81 & 83,20 & 16,75 & 25 & 125 & 1,979 & 0,119 & \\
\hline $32-42$ yaş & 30 & 84,43 & 14,24 & 54 & 121 & & & \\
\hline $43-55$ yaş & 40 & 84,45 & 15,82 & 54 & 111 & & & \\
\hline 55 yaş ve üstü & 22 & 92,18 & 10,21 & 79 & 110 & & & \\
\hline \multicolumn{9}{|c|}{ Eğitim Durumu } \\
\hline Lise & 33 & 76,27 & 17,24 & 25 & 99 & 6,995 & $0,001 *$ & $1-2$ \\
\hline Lisans & 84 & 85,95 & 14,50 & 49 & 121 & & & $1-3$ \\
\hline Lisansüstü & 56 & 88,23 & 14,51 & 53 & 125 & & & \\
\hline \multicolumn{9}{|l|}{ Gelir durumu } \\
\hline İyi & 79 & 86,56 & 14,16 & 25 & 113 & 2,471 & 0,088 & \\
\hline Orta & 81 & 82,27 & 16,76 & 53 & 121 & & & \\
\hline Düşük & 13 & 90,46 & 14,14 & 71 & 125 & & & \\
\hline \multicolumn{9}{|l|}{ Medeni Durum } \\
\hline Evli & 106 & 84,30 & 14,63 & 49 & 121 & 0,879 & 0,417 & \\
\hline Bekar & 48 & 84,27 & 18,43 & 25 & 125 & & & \\
\hline Boşanmış & 19 & 89,32 & 12,55 & 71 & 110 & & & \\
\hline
\end{tabular}

$* p<0,05$

Tablo 7. Katılımcıların yaş grubu, eğitim, gelir ve medeni durumlarına göre psikolojik matematik okuryazarlığı öz-yeterlilik ölçeği puanlarının karşılaştırılmasına ilişkin varyans analizi (ANOVA) sonuçları verilmiştir.
Tablo 7. incelendiğinde araştırmaya dahil edilen bireylerin yaş gruplarına, gelir ve medeni durumlarına göre matematik okuryazarlığı özyeterlilik ölçeği puanları arasında istatistiksel olarak anlamlı bir fark olmadığı saptanmıştır $(\mathrm{p}>0,05)$.

Tablo 8. Katılımcıların bütçe planlaması yapma durumuna göre psikolojik iyi oluş ölçeği puanlarının karşılaştırılması $(\mathbf{n}=173)$ 


\begin{tabular}{|c|c|c|c|c|c|}
\hline & $\mathbf{n}$ & $\overline{\bar{x}}$ & $\mathbf{s}$ & $\mathbf{T}$ & $\mathbf{P}$ \\
\hline \multicolumn{6}{|c|}{ Aylık/haftalık bütçe planlaması yapma } \\
\hline Evet & 123 & 46,87 & 4,87 & 0,852 & 0,395 \\
\hline Hayır & 50 & 46,20 & 4,18 & & \\
\hline \multicolumn{6}{|c|}{$\begin{array}{l}\text { Kredi kartı harcamalarındaki } \\
\text { gider farklılıklarım hesaplama }\end{array}$} \\
\hline Evet & 124 & 46,76 & 5,05 & 0,453 & 0,651 \\
\hline Hayır & 48 & 46,40 & 3,64 & & \\
\hline \multicolumn{6}{|c|}{$\begin{array}{l}\text { Aylık Elektrik/su/telefon/gaz } \\
\text { gibi giderlerdeki farklılıkları hesaplama }\end{array}$} \\
\hline Evet & 109 & 46,98 & 4,82 & 1,120 & 0,264 \\
\hline Hayır & 64 & 46,16 & 4,43 & & \\
\hline \multicolumn{6}{|c|}{ Günlük yiyecek, içecek harcamalarını hesaplama } \\
\hline Evet & 89 & 46,67 & 4,96 & 0,033 & 0,974 \\
\hline Hayır & 83 & 46,65 & 4,42 & & \\
\hline \multicolumn{6}{|c|}{$\begin{array}{l}\text { Aylık/yıllık ev eşyası, giyim, araba alımı, } \\
\text { tatil, ulaşım, yakıt, sigorta gibi giderleri hesaplama }\end{array}$} \\
\hline Evet & 135 & 46,76 & 4,75 & 0,419 & 0,676 \\
\hline Hayır & 38 & 46,39 & 4,48 & & \\
\hline \multicolumn{6}{|c|}{$\begin{array}{l}\text { Aylık/yıllık okul, kurs gibi eğitim } \\
\text { ve sağlık giderleri hesaplama }\end{array}$} \\
\hline Evet & 109 & 47,23 & 4,55 & 2,046 & $0,042 *$ \\
\hline Hayır & 64 & 45,73 & 4,79 & & \\
\hline
\end{tabular}

$* p<0,05$

Tablo 8.'de katılımcıların bütçe planlaması yapma durumuna göre psikolojik iyi oluş ölçeği puanlarının karşılaştırılması amacıyla yapılan bağımsız örneklem t testi sonuçları verilmiştir.

Tablo 8. incelendiğinde katılımcıların Aylık/yıllık okul, kurs gibi eğitim ve sağlık giderlerini hesaplama durumlarına göre psikolojik iyi oluş ölçeği puanları arasında istatistiksel olarak anlamlı bir fark olduğu saptanmıştır $(\mathrm{p}<0,05)$. Aylık/yıllık okul, kurs gibi eğitim ve sağlık giderlerini hesaplayan bireylerin psikolojik iyi oluş ölçeği puanları, hesaplamayanlara göre anlamlı düzeyde yüksektir.

Tablo 9. Katılımcıların bütçe planlaması yapma durumuna göre matematik okuryazarlı̆̆ı öz-yeterlilik ölçeği puanlarının karşılaştırılması $(n=173)$

\begin{tabular}{|c|c|c|c|c|c|}
\hline & $\mathbf{N}$ & $\bar{x}$ & $\mathbf{S}$ & $\mathbf{t}$ & $\mathbf{P}$ \\
\hline \multicolumn{6}{|c|}{ Aylık/haftalık bütçe planlaması yapma } \\
\hline Evet & 123 & 84,84 & 16,25 & $-0,009$ & 0,993 \\
\hline Hayır & 50 & 84,86 & 13,91 & & \\
\hline \multicolumn{6}{|c|}{$\begin{array}{l}\text { Kredi kartı harcamalarındaki } \\
\text { gider farklılıklarını hesaplama }\end{array}$} \\
\hline Evet & 124 & 85,31 & 15,27 & 0,504 & 0,615 \\
\hline Hayır & 48 & 83,98 & 16,41 & & \\
\hline \multicolumn{6}{|c|}{$\begin{array}{l}\text { Aylık Elektrik/su/telefon/gaz } \\
\text { gibi giderlerdeki farklılıkları hesaplama }\end{array}$} \\
\hline Evet & 109 & 85,20 & 15,11 & 0,394 & 0,694 \\
\hline
\end{tabular}




\begin{tabular}{|c|c|c|c|c|c|}
\hline Hayır & 64 & 84,23 & 16,42 & & \\
\hline \multicolumn{6}{|c|}{ Günlük yiyecek, içecek harcamalarını hesaplama } \\
\hline Evet & 89 & 84,69 & 16,99 & $-0,066$ & 0,947 \\
\hline Hayır & 83 & 84,84 & 14,01 & & \\
\hline \multicolumn{6}{|c|}{$\begin{array}{l}\text { Aylık/yıllık ev eşyası, giyim, araba alımı, } \\
\text { tatil, ulaşım, yakıt, sigorta gibi giderleri hesaplama }\end{array}$} \\
\hline Evet & 135 & 85,50 & 15,25 & 1,039 & 0,300 \\
\hline Hayır & 38 & 82,53 & 16,65 & & \\
\hline \multicolumn{6}{|c|}{$\begin{array}{l}\text { Aylık/yıllık okul, kurs gibi eğitim } \\
\text { ve sağlık giderleri hesaplama }\end{array}$} \\
\hline Evet & 109 & 86,97 & 14,56 & 2,378 & $0,019 *$ \\
\hline Hayır & 64 & 81,22 & 16,65 & & \\
\hline
\end{tabular}

Katılımcıların bütçe planlaması yapma durumuna göre matematik okuryazarlığı öz-yeterlilik ölçeği puanlarının karşılaştırılması amacıyla yapılan varyans analizi (ANOVA) sonuçları Tablo 9.'da verilmiştir.

Araştırma kapsamına alınan bireylerin aylık/yıllık okul, kurs gibi eğitim ve sağlık giderlerini hesaplama durumlarına göre matematik okuryazarlığı öz-yeterlilik ölçeği puanları arasında istatistiksel olarak anlamlı bir fark olduğu saptanmıştır $(p<0,05)$. Aylık/yıllık okul, kurs gibi eğitim ve sağlık giderlerini hesaplayan bireylerin matematik okuryazarlığı öz-yeterlilik ölçeği puanları, hesaplamayanlara göre anlamlı düzeyde yüksek olduğu saptanmıştır.

Tablo 10. Katılımcıların psikolojik iyi oluş ölçeği puanları ile matematik okuryazarlığı öz-yeterlilik ölçeği puanları arasındaki ilişki $(n=173)$

\begin{tabular}{|c|c|c|c|}
\hline & & 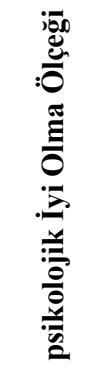 & 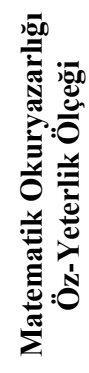 \\
\hline \multirow{2}{*}{ Psikolojik İyi Olma Ölçeği } & $\mathrm{r}$ & 1,00 & 0,29 \\
\hline & $\mathrm{p}$ & & $0,00^{*}$ \\
\hline \multirow{2}{*}{$\begin{array}{c}\text { Matematik Okuryazarlı̆̆ı } \\
\text { Öz-Yeterlik Ölçeği }\end{array}$} & $\mathrm{r}$ & 0,29 & 1,00 \\
\hline & $\mathrm{p}$ & $0,00 *$ & \\
\hline
\end{tabular}

$* p<0,05$

Tablo 10.'da katılımcıların psikolojik iyi oluş ölçeği puanları ile matematik okuryazarlığı özyeterlilik ölçeği puanları arasındaki ilişkin saptanması amaciyla yapılan Pearson korelasyon analizi sonuçları verilmiştir.

Tablo 10. incelendiğinde araştırma kapsamına alınan bireylerin psikolojik iyi oluş ölçeği puanları ile matematik okuryazarlığı öz-yeterlilik ölçeği puanlar arasında istatistiksel olarak anlamlı bir korelasyon olduğu saptanmıştır $(\mathrm{p}<0,05)$. Buna göre katılımcıların matematik okuryazarlığı öz- yeterlilik ölçeği puanlar arttıkça, psikolojik iyi oluş ölçeği puanlar da artmaktadır.

\section{Tartışma}

Matematik okuryazarlığı, bireylerin günlük yaşamlarında da kullandıkları önemli bir beceridir (Kabael \& Barak, 2016). Bu nedenle bireylerin hayat pahalılı̆̆ karşısında sağlıklı bir psikolojik iyi oluşa sahip olabilmeleri için matematik okuryazarlığı becerisine sahip olmaları beklenmektedir. $\mathrm{Bu}$ bilgiler doğrultusunda yapılan 
çalışma ile Matematik Okuryazarlığın aile bütçesini belirlemedeki önemi ile aile bütçesini planlamanın, yetişkinlerin psikolojik iyi oluşları üzerinde etkili olup olmadığının ortaya konması amaçlanmaktadır.

Çalışmada, katılımcıların matematik okuryazarlığı öz-yeterlilik ölçeği puanlar arttıkça, psikolojik iyi oluş ölçeği puanlar da artmaktadır. Bununla birlikte, aylık/yıllık okul, kurs gibi eğitim ve sağlık giderlerini hesaplayan bireylerin hesaplamayan bireylere göre psikolojik iyi oluş ölçeği puanları ve matematik okuryazarlığı öz-yeterlilik ölçeği puanları anlamlı düzeyde yüksek olduğu görülmüştür. Literatürdeki çalışmalara bakıldığında öznel iyi oluş ile öz-yeterlik arasında pozitif yönde anlamlı ilişkiler olduğu görülmüştür (Cicognani, Albanesi, ve Zani, 2008; Telef ve Ergün, 2013). Telef ve Ergün (2013)'e göre özyeterlikler arttıkça, öznel iyi oluşların da arttığı görülmektedir. Cicognani, Albanesi ve Zani (2008)'e göre öz yeterlik; kişisel bir kaynak olmakta ve doğrudan iyi oluşu artırmaktadır. Araştırmaya dahil edilen bireylerin cinsiyetlerine göre matematik okuryazarlığı öz-yeterlilik ölçeği puanları arasında istatistiksel olarak anlamlı bir fark olduğu tespit edilmiştir. Erkek bireylerin matematik okuryazarlığg 1 öz-yeterlilik ölçeği puanları, kadın bireylere göre daha yüksek bulunmuştur. Yapılan başka çalışmalara bakıldığında da erkek bireylerin matematik okuryazarlığı öz-yeterlilik puanları yüksek olduğunu ortaya koymaktadır (Özgen ve Bindak, 2011 Yenilmez, 2010). Tan (1996) yapmış olduğu çalışmada katılımcıların cinsiyetlerine, çocuk sahibi olma durumuna ve aile tipine göre psikolojik iyi oluş düzeyleri arasında fark olduğunu saptamıştır. Buna karşın bu çalışmada cinsiyet ile psikolojik iyi oluşu arasında fark olmaması katılımcı sayısının azlığı ve cinsiyet dağılımının eşit olamamasıyla açıklanabilmektedir. Araştırma kapsamına alınan bireylerin cinsiyet dışındaki yaş gruplarına, eğitim, medeni durum ve gelir düzeyleri gibi diğer demografik değişkenleri ile psikolojik iyi oluş ölçeğinde aldıkları puanlar arasında istatistiksel olarak anlamlı bir fark olduğu görülmüştür. Tuzgöl-Dost (2010) yapmış olduğu çalışmada gelir durumu ile psikolojik iyi oluş arasında fark olduğunu tespit etmiştir. Bu fark gelir durumunu iyi ve orta olarak tanımlayan bireylerden kaynaklanmakta olup, gelir durumunu iyi olarak tanımlayan katılımcıların psikolojik iyi oluş ölçeğinden aldıkları puanlar gelir durumunu orta olarak tanımlayanlara göre anlamlı düzeyde yüksektir. Bununla birlikte Tatlığlu (2015) gelir artışı ve mutluluk düzeyleri arasında doğru orantılı bir ilişki olduğunu ortaya koymuştur. Bu konuda yapılan diğer çalışmalarda incelendiğinde, bireylerin ihtiyaçlarını karşılama düzeyi ile psikolojik ve fiziksel iyi oluşları arasında anlamlı bir ilişki olduğu görülmektedir. Konu kapsamında yapılan diğer çalışmalarda bireyin sosyo-ekonomik durumunun iyi oluşu, diğer demografik özelliklerden yaş ve cinsiyete göre psikolojik iyi olmak üzerinde daha güçlü yordayıcı olduğu tespit edilmiştir (Diener \& Diener 1996; Myers \& Diener, 1995).

\section{Sonuç ve Öneriler}

Sonuç olarak, bireylerin matematik okuryazarlığ öz-yeterliliklerinin arttıkça, psikolojik iyi oluş hallerinin de arttığı ortaya çıkmıştır. Bu hayat pahalılığı ve ekonomik kriz sürecinde bireylerin sağlıklı bir psikolojik iyi oluşa sahip olabilmeleri ve krizi doğru yönetebilmeleri adına matematik okuryazarlığına sahip olmanın aile bütçesini belirlemedeki önemi ile aile bütçesini planlamanın, yetişkinlerin psikolojik iyi oluşları üzerine doğrudan etkisi olduğu tespit edilmiştir. $\mathrm{Bu}$ araştırma sonucunda konuyla ilgili yapılacak diğer çalışmalara katkı sunması ve söz konusu değişkenler arasındaki ilişsilere bütüncül bir bakış getirmesi beklenmektedir. Daha sonra yapılacak çalışmaların psikolojik iyi-oluşa etkisi olabileceği düşünülen başka değişkenlerin daha geniş örneklem gruplarında ve farklı yaş gruplarında incelenmesinin yararlı olabileceği düşünülmektedir. Araştırma sonucundan hareketle bu alanda yapılacak çalışmalara ihtiyaç duyulduğu ortaya çıkmıştır. Hem yabancı hem de yerli literatürde bu değişkenlerle çok az sayıda çalışma olduğu ve alanın bu alanda genişletilme ihtiyacı olduğu görülmüştür.

\section{Kaynaklar}

Akdoğan, A. ve Polatcı S, (2013). Psikolojik Sermayenin Performans Üzerindeki Etkisinde İș Aile Yayılımı ve Psikolojik İyi Oluşun Etkisi. Atatürk Üniversitesi Sosyal Bilimler Enstitüsü Dergisi, 17 (1): 273-293.

Altıntaş, E., Özdemir, A. ve Kerpiç, A. (2012). Öğretmen Adaylarının Matematik Okuryazarlığı Özyeterlik Algılarının Bölümlere Göre Karşılaştırılması. Trakya Universitesi Eğitim Fakültesi Dergisi, Cilt 2, Sayı 2, 26-34.

Cicognani, E., Albanesi C., \& Zani, E. (2008). The Impact of Residential Context on Adolescents' Subjective Well Being. Journal of Community \& Applied Social Psychology, 18, 558575.
Diener, E. \& Diener, C. (1996). Most People are Happy. American Psychological Society, 7 (3), 181-185.

Diener, E., Wirtz, D., Tov, W., Kim-Prieto, C., Choi, D., Oishi, S., \& Biswas-Diener, R. (2010). New Well-Being Measures: Short Scales To Assess Flourishing and Positive and Negative Feelings. Social Indicators Research, 97, 143-156.

Eroğlu, Y. ve Güler, N. (2015). Koşullu Öz-Değer, Riskli İnternet Davranışları ve Siber Zorbalık/Mağduriyet Arasındaki İlişkinin İncelenmesi. Sakarya University Journal of Education, 5/3 ss. 118-129.

Güneş, G. ve Gökçek, T. (2013) Öğretmen Adaylarının Matematik Okuryazarlık Düzeylerinin Belirlenmesi. Dicle Üniversitesi Ziya Gökalp Eğitim Fakültesi Dergisi, 20 70-79. 
Kabael, T., \& Barak, B. (2016). Research of middle school preservice mathematics teachers' mathematical literacy on PISA items. Turkish Journal of Computer and Mathematics Education, 7(2), 321-349

Kaplan, K. (2016). Evli Bireylerde Toplumsal Cinsiyet Rollerine İlişkin Tutumların, Evlilik Doyumuna ve Psikolojik İyi Oluş Durumuna Etkisinin İncelenmesi. Yüksek Lisans Tezi, Beykent Üniversitesi Sosyal Bilimler Enstitüsü, İstanbul.

Myers, D.G. \& Diener, E. (1995). Who is Happy? Psychological Science, 6 (1), 10-17.

Özgen, K. ve Bindak, R. (2008). Matematik Okuryazarlı̆̆ı Özyeterlilik, Ölçeğinin Geliştirilmesi. Kastamonu Eğitim Dergisi, 16(2), 517-528.

Şarlak, Z. (2012). Aile Bütçesi ve Kaynak Yönetimi. İstanbul: Edam.

Tan, M. (1996) "Bir Kadın Mesleği: Öğretmenlik". Kadın Gerçekleri (Haz: Necla Arat). İstanbul: Say Yayınları.

Tatlıoğlu, K. (2015). Üniversite Öğrencilerinin Aylık Gelir Ve Harcama Düzeyi İle Psikolojik İyi Oluşları Arasındaki İlişkinin İncelenmesi (Bingöl Üniversitesi Örneği). Elektronik Sosyal Bilimler Dergisi, 14(55),1-15
Telef, B.B. ve Ergün, E. (2013). Lise Öğrencilerinin Öznel İyi Oluşlarının Yordayıcısı Olarak Öz-Yeterlik. Kuramsal Eğitimbilim Dergisi - Journal of Theoretical Educational Science, 6(3), 423-433.

Tuzgöl-Dost, M. (2010). Güney Afrika ve Türkiye'deki Üniversite Öğrencilerinin Bazı Değişkenlere Göre Öznel İyi Oluş ve Yaşam Doyumlarının İncelenmesi. Eğitim ve Bilim, 35(158), 75-89.

Yenilmez, K. (2010). Öğretmen Adaylarının Matematik Okuryazarlı̆̆ Özyeterlik İnançları. 9. Matematik Sempozyumu Bildiri Kitab1, 455-460, Ekim, Karadeniz Teknik Üniversitesi, Trabzon.

Zehir, K. ve Zehir, H. (2016). İlköğretim Matematik Öğretmen Adaylarının Matematik Okuryazarlığı Öz-yeterlik İnanç Düzeylerinin Çeşitli Değişkenler Açısından İncelenmesi. Uluslararası Eğitim, Bilim ve Teknoloji Dergisi International Journal of Education, Science and Technology 2016, Cilt 2, Say1 2, 104-117. 